\title{
PENERAPAN PROGRAM LINIER MENGGUNAKAN METODE DUAL SIMPLEKS DAN METODE QUICK SIMPLEKS UNTUK MEMINIMUMKAN BIAYA (STUDI KASUS: KELOMPOK WANITA TANI (KWT) SENTOSA SANTUL)
}

\author{
Elfira Safitri ${ }^{*}$, Sri Basriati ${ }^{2}$, Elvina Andiani ${ }^{3}$ \\ 1,2,3Program Studi Matematika, UIN Suska Riau \\ Email : ${ }^{1}$ elfira.safitri@uin-suska.ac.id, ${ }^{2}$ sribasriati@uin-suska.ac.id, ${ }^{3}$ elvinaandiani19@gmail.com
}

\begin{abstract}
The Sentosa Santul Women Farmers Group (KWT) is a group of women farmers in Dusun Santul, Kampar Utara District an is engaged in the field of food crops is chili. The Sentosa Santul Women Farmers group (KWT) uses 4 types of fertilizers for chili plant fertilization, namely hydro complex fertilizer, phonska, NPK Zamrud and goat manure.The KWT wants the minimum fertilizer cost but the nutrients in the plants are met. The method used in this research is the dual simplex method and the quick simplex method. The purpose of this study is to determine the minimum costs that must be incurred by the Womens Farmer Group (KWT) for fertilization using the dual simplex method and the quick simplex method to obtain an optimum and feasible solution. For the dual simplex method, the optimum and feasible solution were obtained using the Gauss Jordanelimination. While the quick simplex method, the solution is illustrated using a matrix to reduce the number of iterations needed to achieve the optimal solution. Based on the research result, it is found that the quick simplex method is more efficient than the dual simplex method. This can be seen from the number of iterations carried out. Dual simplex method iteration there are two iterations and quick simplex one iteration. The dual simplex method and the quick simplex method produce the same value.
\end{abstract}

Keywords: Dual simplex method, Feasible, Iteration, Quick simplex method

\begin{abstract}
Abstrak. Kelompok Wanita Tani (KWT) Sentosa Santul merupakan kelompok wanita tani di Dusun Santul, Kecamatan Kampar Utara dan bergerak dalam bidang tanaman pangan yaitu cabai. Kelompok wanita tani (KWT) Sentosa Santul menggunakan 4 jenis pupuk untuk pemupukan tanaman cabai yaitu pupuk Hidrokompleks, Phonska, NPK Zamrud dan pupuk kandang Kambing. KWT tersebut menginginkan biaya pemupukan seminimal mungkin tetapi unsur hara pada tanaman terpenuhi. Metode yang digunakan dalam penelitian ini adalah metode dual simpleks dan metode quick simpleks. Tujuan dari penelitian ini adalah mengetahui biaya minimum yang harus dikeluarkan Kelompok Wanita Tani (KWT) untuk pemupukan menggunakan metode dual simpleks dan metode quick simpleks untuk mendapatkan solusi yang optimum dan fisibel. Penyelesaian metode dual simpleks, solusi optimum dan fisibel diperoleh menggunakan eliminasi Gauss Jordan. Sedangkan metode quick simpleks, solusi penyelesaian di ilustrasikan dengan menggunakan matriks untuk mengurangi jumlah iterasi yang diperlukan mencapai solusi yang optimal. Berdasarkan hasil penelitian diperoleh bahwa metode quick simpleks lebih
\end{abstract}


efisien dibandingkan dengan metode dual simpleks. Hal ini, dapat dilihat dari banyak nya iterasi yang dilakukan dan waktu pengerjaan yang lebih singkat. Iterasi metode dual simpleks terdapat dua kali iterasi dan quick simpleks satu kali iterasi. Metode dual simpleks dan metode quick simpleks menghasilkan nilai yang sama.

Kata kunci: Fisibel, iterasi,metode dual simpleks, metode quick simpleks.

\section{PENDAHULUAN}

Pupuk adalah bahan yang diberikan ke dalam tanah baik yang organik maupun anorganik dengan maksud mengganti kehilangan unsur hara dari dalam tanah yang bertujuan untuk meningkatkan produksi tanaman dalam keadaan lingkungan yang baik. Dalam penggunaan pupuk memerlukan petani yang berpengalaman banyak, sehingga tanaman yang dipupuk tumbuh dengan subur dan pendapatan petani meningkat [6].

Peningkatan pendapatan petani bisa dilihat juga dengan adanya organisasi yang bisa mendapatkan cara pemupukan yang baik dan memperkuat kerjasama diantara sesama petani wanita dalam kelompok tani dan antar kelompok tani serta dengan pihak lain adalah dengan adanya organisasi Kelompok Wanita Tani (KWT). Salah satunya adalah organisasi Kelompok Wanita Tani (KWT) Sentosa Santul yang terdapat di Dusun Santul, Kecamatan Kampar Utara dan kelompok wanita tani ini bergerak dalam bidang tanaman pangan, salah satunya yang ditanam adalah cabai [7].

Salah satu faktor yang menunjang tanaman untuk tumbuh dan berproduksi secara optimal adalah ketersediaan unsur hara dalam jumlah yang cukup dalam tanah. Jika tanah tidak dapat menyediakan unsur hara yang cukup bagi tanaman, maka pemberian pupuk perlu dilakukan untuk memenuhi kekurangan tersebut. Pemberian pupuk tidak cukup hanya melihat keadaan tanah dan lingkungan saja, tetapi harus mempertimbangkan kebutuhan pokok unsur hara tanaman tersebut [5].

Penanaman cabai pada umumnya petani kurang memperhatikan Penggunaan pupuk. Petani memberikan penggunaan jenis dan dosis pupuk yang berbeda-beda walaupun dengan luas tanah yang sama. Petani yang memiliki modal banyak, dalam penggunaan pupuk cenderung lebih banyak. Sedangkan petani yang memiliki modal sedikit cenderung meminimalkan penggunaan pupuk untuk mengurangi biaya yang dikeluarkan [1]. Meminimalkan penggunaan pupuk tanpa mempertimbangkan kebutuhan unsur hara tanaman karena biaya yang terbatas terjadi pada kelompok wanita tani (KWT) Sentosa Santul. Penggunaan pupuk dilakukan secara manual tanpa diketahui apakah jumlahnya sudah optimal atau belum. Akibatnya, hasil produksi cabai menjadi tidak maksimal karena kurangnya kandungan unsur hara yang dibutuhkan. Dalam mengatasi keterbatasan yang dimiliki guna meminimumkan biaya keseluruhan, maka perlu dilakukan optimasi dengan cara program linear [7].

Solusi dasar dari metode simpleks dengan $Z_{j}-C_{j} \geq 0$ akan memiliki dua kemungkinan solusi, yaitu fisibel dan tidak fisibel. Solusi yang fisibel akan menjadi solusi yang optimum dan untuk solusi yang tidak fisibel dapat dioptimumkan menjadi solusi yang fisibel dengan menggunakan metode dual simpleks. Penyelesaian metode dual simpleks sangat mirip dengan metode simpleks, perbedaan antara keduanya adalah terletak pada leaving variabel dan entering variabel. Entering variabel pada dual simpleks adalah variabel basis yang memiliki nilai negatif terbesar. Leaving variabel pada dual simpleks adalah ditentukan perbandingan rasio antara koefisien baris (z) dengan koefisien leaving variabel [3]. 
Ada suatu pendekatan baru untuk menyelesaikan permasalahan program linier yaitu pendekatan quick simpleks. Solusi penyelesaian dengan menggunakan quick simpleks di ilustrasikan dengan menggunakan matriks untuk mengurangi jumlah iterasi yang diperlukan mencapai solusi yang optimal. Metode dual simpleks memakai tabel simpleks dengan perulangan/iterasi, perlu banyak langkah dan ketelitian tinggi sedangkan quick simpleks hanya sekali iterasi. Maka, quick simpleks baik secara tabel dan bentuk matriks akan digunakan dalam penyelesaian masalah ini [12].

Penelitian terdahulu yang berkaitan dengan metode quick simpleks dapat dilihat dari jurnal penelitian yang berkaitan dengan hal tersebut yaitu penelitian yang dilakukan oleh Vaidya, dkk [10] yang berjudul "Approximation algorithm for optimal solution to the linear programming problem". Dalam penelitian ini membahas tentang algoritma alternative baru untuk dua fase metode simpleks dan pemograman linier. Metode ini melibatkan lebih sedikit iterasi dari metode simpleks biasa.

Selanjutnya, penelitian Vaidya, dkk [8] yang berjudul "Comparision between various entering vector criteria with quick simplex algorithm for optimal solution to the linear programming problem". Dalam penelitin tersebut dibahas mengenai memecahkan masalah pemrograman linier menggunakan metode simpleks dan membandingkan metode quick simpleks dengan metode lain untuk memperkenalkan vektor dengan berbagai kriteria mencapai solusi optimal. Metode ini melibatkan iterasi yang lebih sedikit dari pada metode simpleks atau paling banyak angka yang sama karena metode ini mencoba untuk mengganti lebih dari satu variabel dasar secara bersamaan.

Penelitian lain dengan pembahasan yang sama juga dilakukan oleh Vaidya, dkk [9] yang berjudul "Quick Simplex Algorithm For Optimal Solution to the Linear Programming Problem Along with Theoretical Proof of Formulae”. Dalam penelitian tersebut dibahas mengenai menyelesaikan solusi linear programming menggunakan metode simpleks dan diaplikasikan dengan metode quick simpleks. Metode quick simpleks mencoba untuk menggantikan lebih dari satu variabel dasar simultan sehingga melibatkan lebih sedikit iterasi atau pada jumlah yang paling sama dari pada dalam metode simpleks.

Selanjutnya penelitian lain dilakukan oleh Vaidya dan Kasturiwale [11] yang berjudul “ Application Of Quick Simplex Method (A New Approach) On Two Phase Method" . Dalam penelitian tersebut dibahas mengenai menyelesaikan metode simpleks dua fase dan diaplikasikan dengan metode quick simpleks pada fase I dan fase II, di ilustrasikan dengan memberikan solusi untuk menyelesaikan masalah metode dua fase simpleks tersebut. Dan menunjukakan bahwa iterasi yang dibutuhkan sama atau kurang, tetapi iterasi yang diperlukan tidak pernah lebih dibandingkan dengan Metode Simpleks.

Kemudian juga dilakukan oleh Vaidya, dkk [12] yang berjudul ."Application Of Quick Simplex Method On The Dual Simplex Method (A New Approach) ". Dalam penelitian tersebut dibahas mengenai menyelesaikan metode quick simpleks menggunakan metode dual simpleks. Metode quick simpleks mencoba untuk menggantikan lebih dari satu variabel dasar simultan sehingga melibatkan lebih sedikit iterasi atau pada jumlah yang paling sama dari pada dalam metode dual simplek standar.

Berdasarkan penelitian Vaidya [12] penulis tertarik melakukan penelitian mengenai metode quick simpleks dengan variabel dan fungsi kendala serta kasus yang berbeda. Adapun tujuan dari penelitian ini adalah mengetahui biaya minimum yang harus dikeluarkan Kelompok Wanita Tani (KWT) untuk pemupukan menggunakan metode dual simpleks dan metode quick simpleks untuk mendapatkan solusi yang optimum dan fisibel. 


\section{METODE DAN BAHAN PENELITIAN}

\subsection{Metode Dual Simpleks}

Metode dual simpleks adalah persoalan program linier yang udah optimum (berdasarkan kondisi optimalisasi), tetapi belum fisibel (ada pembatas nonnegatif yang tidak terpenuhi), maka persoalan tersebut harus diselesaikan dengan menggunakan metode dual simpleks [2]. Langkah-langkah dalam menyelesaikan metode dual simpleks sebagai berikut:

a. Mengubah model program linier kedalam bentuk standar dengan mengubah semua kendala menjadi pertidaksamaan $\leq$ dan kemudian tambahkan variabel slack.

b. Menentukan leaving variabel

Yang menjadi leaving variable pada dual simpleks adalah variabel basis yang memiliki harga negatif terbesar. Jika semua variabel basis telah berharga positif atau nol, berarti keadaan fisibel telah tercapai.

c. Menentukan entering variable

Terdapat dua cara menentukan entering variable yaitu:

1. Menentukan perbandingan (rasio) antara koefisien persamaan $z$ dengan koefisien persamaan leaving variable. Abaikan penyebut positif atau nol. Jika semua penyebut berharga positif atau nol, berarti persoalan yang bersangkutan tidak memilki solusi fisibel.

2. Untuk persoalan minimasi, entering variable adalah variabel dengan rasio terkecil, sedangkan untuk persoalan maksimasi, entering variable adalah variabel dengan rasio absolut terkecil.

d. Melakukan eliminasi Gauss Jordan.

e. Solusi dikatakan optimal untuk kasus maksimasi dan minimasi jika nilai ruas kanan pada pembatas tidak bernilai negatif dan dikatakan solusi optimum dan fisibel [2].

\subsection{Metode Quick Simpleks}

Langkah-Langkah dalam penyelesaian metode quick simpleks [12] sebagai berikut :

a. Mengubah model kedalam bentuk standar.

b. Menentukan leaving variabel

Leaving variable dipilih yang memiliki nilai negatif dari variabel basis.

c. Menentukan entering variabel.

Entering variable dipilih ketika elemen-elemen pivot dalam entering variable berada dalam basis yang berbeda dan ditentukan dari perbandingan antara koefisien persamaan $z$ dengan koefisien leaving variable dimulai dari negatif terbesar. Jika terdapat nilai entering variable yang sama, maka dipilih salah satu yang terdapat nilai leaving variable yang negatif terbesar.Untuk persoalan minimasi entering variable adalah variabel dengan rasio positif terkecil, sedangkan untuk persoalan maksimasi entering variable adalah absolut terkecil.

d. Menentukan nilai R.

$\mathrm{R}$ adalah determinan matriks dari $\mathrm{A}$.

Rumus $R$ untuk dua variabel

$$
R=\operatorname{det}\left|\begin{array}{ll}
x_{11} & x_{12} \\
x_{21} & x_{22}
\end{array}\right|
$$


Rumus $R$ untuk tiga variabel:

$$
R=\operatorname{det}\left|\begin{array}{lll}
x_{11} & x_{12} & x_{13} \\
x_{21} & x_{22} & x_{23} \\
x_{31} & x_{32} & x_{33}
\end{array}\right|
$$

e. Menentukan elemen baru dengan menggunakan metode quick simpleks. Elemen baru diperoleh dari rasio dua determinan, yang penyebutnya adalah $\mathrm{R}$. Menentukan metode quick simpleks menggunakan dua variabel atau $n>2$ variabel. Ada dua formulasi rumus yang terdapat pada metode quick simpleks yaitu:

1. Jika terdapat dua variabel mencari nilai elemen dalam tabel simpleks baru menggunakan rumus yang dilihat pada Tabel 1 berikut:

Tabel 1. Tabel mencari nilai $x_{1}^{* *}, x_{2}^{* *}, s_{3}^{* *}$ dan $s_{4}^{* *}$

$\begin{aligned} x_{1}^{* *}=\frac{(-1)^{1}\left|\begin{array}{ll}x_{12} & x_{13} \\ x_{22} & x_{23}\end{array}\right|}{R} & x_{2}^{* *}=\frac{(-1)^{2}\left|\begin{array}{ll}x_{11} & x_{13} \\ x_{21} & x_{23}\end{array}\right|}{R} \\ s_{3}^{* *}=\frac{\left|\begin{array}{lll}x_{11} & x_{12} & x_{13} \\ x_{21} & x_{22} & x_{23} \\ x_{31} & x_{32} & x_{33}\end{array}\right|}{R} & s_{4}^{* *}=\frac{\left|\begin{array}{lll}x_{11} & x_{12} & x_{13} \\ x_{21} & x_{22} & x_{23} \\ x_{41} & x_{42} & x_{43}\end{array}\right|}{R}\end{aligned}$

2. Menghitung metode quick simpleks untuk $n>2$ variabel menggunakan rumus yang terdapat dalam Tabel 2 berikut:

Tabel 2. Tabel untuk $n$ variabel

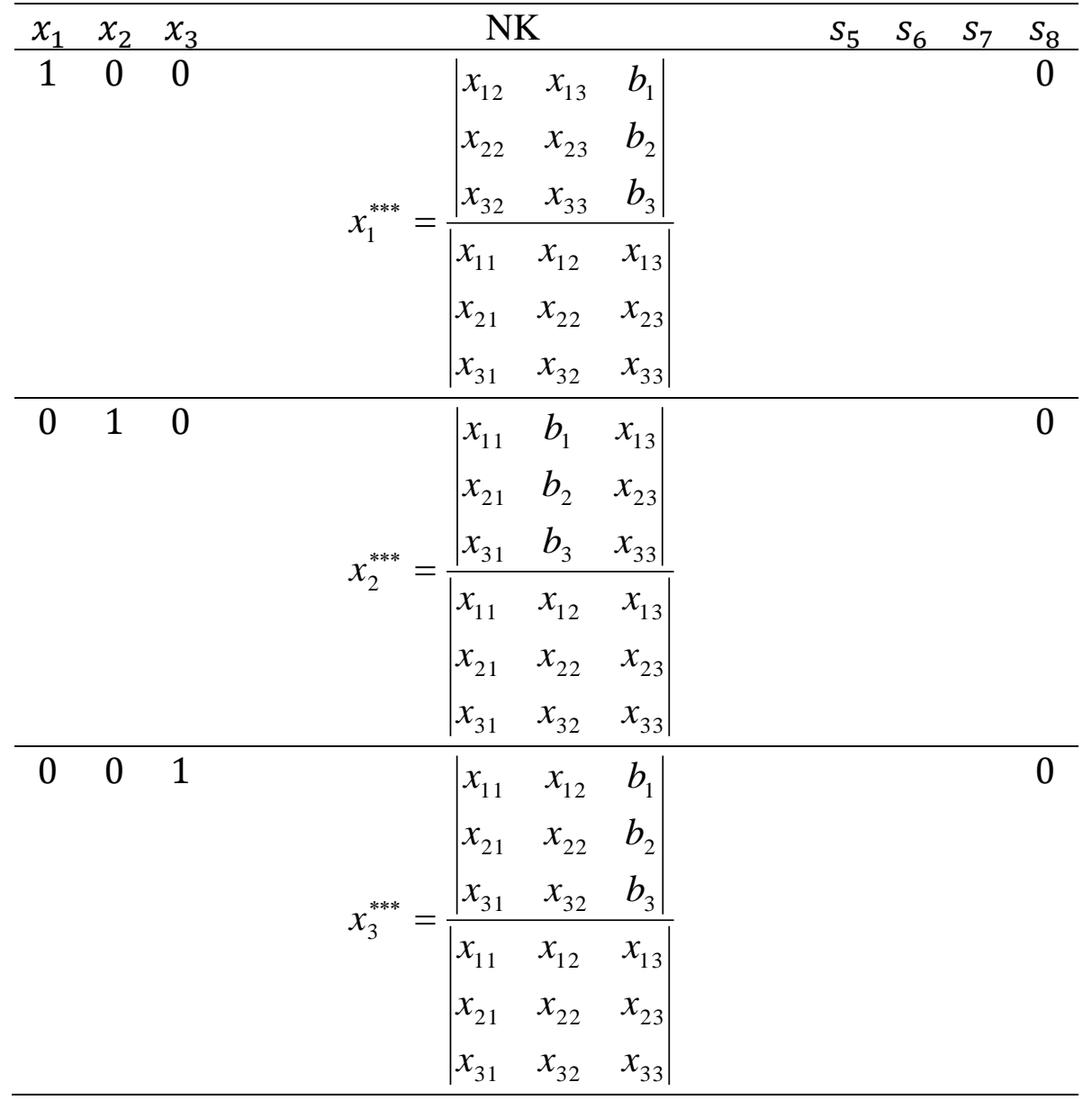




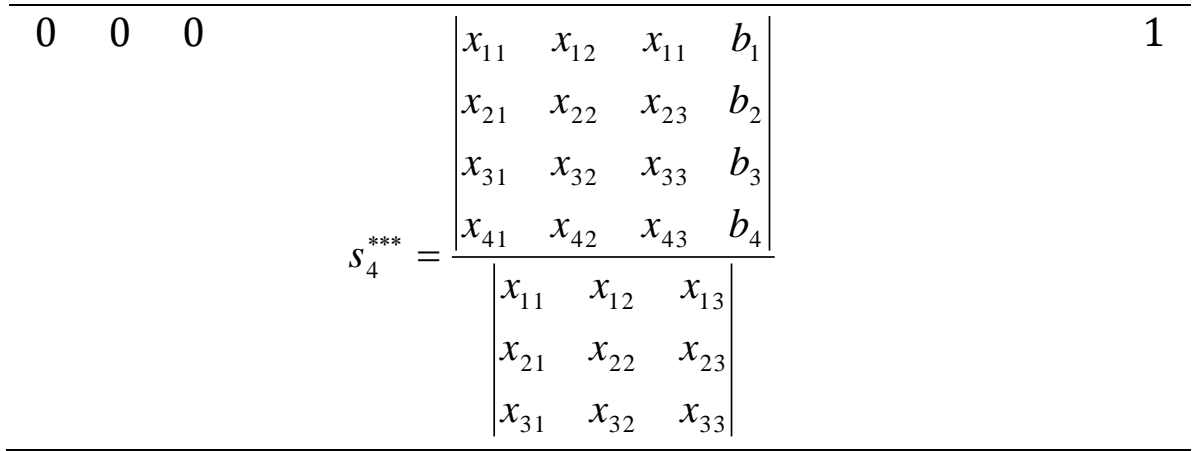

Keterangan :

$x_{i}^{* *} \quad:$ Simbol kolom vektor untuk dua variabel; $i=1,2, \ldots, n$

$x_{i}^{* * * *} \quad:$ Simbol kolom vektor untuk $n>2$ variabel; $i=1,2, \ldots, n$

f. Menentukan niai elemen baru dan memperoleh solusi optimal.

g. Solusi dikatakan optimal pada kasus maksimasi dan minimasi jika nilai ruas kanan pada pembatas tidak bernilai negatif dan solusi dikatakan optimum dan fisibel.

Untuk mendapatkan nilai $z$ menggunakan rumus:

$$
z_{j}-c_{j}=\sum_{i=1}^{n} C_{B} P_{j}-c_{j}
$$

Keterangan:

$C_{B} \quad$ :Koefisien variabel basis fungsi tujuan

$P_{j} \quad$ :Koefisien variabel fungsi kendala, $j=1,2, \ldots, n$

$c_{j} \quad$ :Koefisien variabel fungsi tujuan, $j=1,2, \ldots, n$

\section{HASIL DAN PEMBAHASAN}

\subsection{Gambaran Data}

Penelitian ini menggunakan 4 unsur utama yang dibutuhkan cabai yaitu nitrogen, phosfat, kalium dan sulfur. Setiap satu periode penanaman cabai memerlukan kandungan nitrogen paling sedikit $200 \%$, phosfat paling sedikit $160 \%$, kalium paling sedikit $220 \%$ dan sulfur paling sedikit $100 \%$. Isi kandungan dari empat jenis pupuk tersebut akan dijelaskan di dalam Tabel 3 berikut:

Tabel 3. Jenis Pupuk Tanaman Cabai yang Digunakan

\begin{tabular}{cccccc}
\hline Jenis Pupuk & Jumlah & Kandungan & $\begin{array}{c}\text { UnsurHara } \\
(\%)\end{array}$ & $\begin{array}{c}\text { Per } \\
\text { Karung }\end{array}$ & $\begin{array}{c}\text { HargaPer } \\
\text { Karung }\end{array}$ \\
\cline { 2 - 5 } & Nitrogen & Phosfat & Kalium & Sulfur & \\
\hline Hidrokompleks & $15 \%$ & $9 \%$ & $20 \%$ & $4 \%$ & Rp 225.000 \\
\hline Phonska & $15 \%$ & $15 \%$ & $15 \%$ & $10 \%$ & Rp 115.000 \\
\hline NPK Zamrud & $16 \%$ & $16 \%$ & $16 \%$ & $4 \%$ & $\operatorname{Rp~115.000~}$ \\
\hline $\begin{array}{c}\text { Pupuk Kandang } \\
\text { Kambing }\end{array}$ & $2 \%$ & $1 \%$ & $1 \%$ & $1 \%$ & $\operatorname{Rp~35.000~}$ \\
\hline $\begin{array}{c}\text { Kebutuhan } \\
\text { Minimum }\end{array}$ & $200 \%$ & $160 \%$ & $220 \%$ & $100 \%$ & \\
\hline
\end{tabular}

(Sumber: Skripsi Wazna Ulya, 2019) 
Harga satu karung pupuk jenis Hidrokompleks Rp 225.000, harga satu karung pupuk jenis Phonska Rp115.000, harga satu karung pupuk jenis NPK Zamrud Rp 115.000 dan harga satu karung pupuk jenis pupuk kandang Kambing Rp 35.000.

\subsection{Penyelesaian menggunakan Metode Dual Simpleks}

Metode dual simpleks merupakan salah satu teknik penyelesaian dalam program linier yang digunakan pada persoalan yang udah optimum, tetapi belum fisibel, maka persoalan tersebut harus diselesaikan dengan metode dual simpleks. Langkah-langkah dalam menyelesaikan metode dual simpleks sebagai berikut:

\section{Iterasi 0:}

Langkah 1: Menyusun model program linier

a. Menentukan variabel keputusan

$x_{1}$ : Jumlah pupuk jenis Hidrokompleks yang harus disediakan

$x_{2}$ : Jumlah pupuk jenis Phonska yang harus disediakan

$x_{3}$ : Jumlah pupuk jenis NPK Zamrud yang harus disediakan

$x_{4}$ : Jumlah pupuk jenis pupuk kandang Kambing yang harus disediakan

b. Menentukan fungsi tujuan

$$
\text { Min } z=225000 x_{1}+115000 \alpha_{2}+115000 x_{3}+35000 x_{4}
$$

c. Menentukan fungsi kendala:

$$
\begin{aligned}
& 15 x_{1}+15 x_{2}+16 x_{3}+2 x_{4} \geq 200 \\
& 9 x_{1}+15 x_{2}+16 x_{3}+x_{4} \geq 160 \\
& 20 x_{1}+15 x_{2}+16 x_{3}+x_{4} \geq 220 \\
& 4 x_{1}+10 x_{2}+4 x_{3}+x_{4} \geq 100 \\
& x_{1}, x_{2}, x_{3}, x_{4} \geq 0
\end{aligned}
$$

Langkah 2: Menyusun model program linier kedalam bentuk standar

Karena semua pembatas dalam Persamaan 5 di atas merupakan pembatas dengan tanda $\geq$, maka penyelesaian persoalan tersebut dapat diselesaikan menggunakan metode dual simpleks. Langkah pertama yang harus dilakukan adalah mengubah pembatas tanda $\geq$ menjadi tanda $\leq$ dengan mengalikan -1 pada setiap kendala. Setelah diperoleh pertidaksamaan dengan kendala bertanda $\leq$, kemudian mengubah model ke dalam bentuk standar dengan menambahkan variabel slack yaitu: $s_{1}, s_{2}, s_{3}, s_{4}$ sebagai berikut :

$$
\begin{aligned}
& \text { Min } z=225000 x_{1}+115000 x_{2}+115000 x_{3}+35000 x_{4} \\
& \text { kendala } \\
& -15 x_{1}-15 x_{2}-16 x_{3}-2 x_{4}+S_{1}=-200 \\
& -9 x_{1}-15 x_{2}-16 x_{3}-x_{4}+S_{2}=-160 \\
& -20 x_{1}-15 x_{2}-16 x_{3}-x_{4}+S_{3}=-220 \\
& -4 x_{1}-10 x_{2}-4 x_{3}-x_{4}+S_{4}=-100 \\
& x_{1}, x_{2}, x_{3}, x_{4}, S_{1}, S_{2}, S_{3}, S_{4} \geq 0
\end{aligned}
$$

Langkah 3: Menyusun Persamaan (6) kedalam bentuk tabel awal simpleks

Tabel 4. Awal simpleks untuk metode dual simpleks

\begin{tabular}{cccccccccc}
\hline $\mathrm{BV}$ & $x_{1}$ & $x_{2}$ & $x_{3}$ & $x_{4}$ & $s_{1}$ & $s_{2}$ & $s_{3}$ & $s_{4}$ & Solusi \\
\hline$z$ & -225000 & -115000 & -115000 & -35000 & 0 & 0 & 0 & 0 & 0 \\
\hline$s_{1}$ & -15 & -15 & -15 & -2 & 1 & 0 & 0 & 0 & -200 \\
\hline
\end{tabular}


JOURNAL OF FUNDAMENTAL MATHEMATICS AND APPLICATIONS (JFMA) VOL. 4 NO. 1 (JUN 2021) Available online at www.jfma.math.fsm.undip.ac.id

\begin{tabular}{cccccccccc}
\hline$S_{2}$ & -9 & -15 & -16 & -1 & 0 & 1 & 0 & 0 & -160 \\
\hline$S_{3}$ & -20 & -15 & -16 & -1 & 0 & 0 & 1 & 0 & -220 \\
\hline$S_{4}$ & -4 & -10 & -4 & -1 & 0 & 0 & 0 & 1 & -100 \\
\hline & & & \multicolumn{5}{c}{ Entering variable } \\
\end{tabular}

Langkah 4: Menentukan leaving variable

Leaving variable dipilih berdasarkan variabel basis yang memiliki ruas kanan negatif terbesar yaitu $s_{3}=-220$.

Langkah 5 : Menentukan entering variable

Entering variable dipilih berdasarkan perbandingan (rasio) antara koefisien z dengan koefisien leaving variable. Untuk persoalan minimasi, entering variable adalah variabel dengan rasio positif terkecil. Sehingga diperoleh entering variable yaitu $x_{3}$.

Langkah 6: Melakukan eliminasi Gauus Jordan

Jika nilai iterasi eliminasi Gauus jordan masih terdapat nilai negatif pada nilai ruas kanan pada pembatas, maka iterasi akan terus dilanjutkan. Lanjut ke Langkah 4.

Berdasarkan Tabel 4, karena koefisien pada persamaan $z$ masih bernilai negatif atau nol maka solusi sudah optimal akan tetapi solusi awalnya tidak fisibel dikarenakan nilai ruas kanan berharga negatif. Solusi optimal diperoleh setelah dilakukan iterasi sebanya dua kali. Berikut diperoleh solusi optimal pada iterasi terakhir yang disajikan pada Tabel 5 berikut:

Tabel 5. Iterasi II metode dual simpleks

\begin{tabular}{cccccccccc}
\hline BV & $x_{1}$ & $x_{2}$ & $x_{3}$ & $x_{4}$ & $s_{1}$ & $s_{2}$ & $s_{3}$ & $s_{4}$ & Nilai Ruas Kanan \\
\hline$z$ & -82.400 & 0 & 0 & -26.950 & 0 & 0 & -6.900 & -1.150 & 1.633 .000 \\
\hline$s_{1}$ & 5 & 0 & 0 & -1 & 1 & 0 & -1 & 0 & 20 \\
\hline$s_{2}$ & 11 & 0 & 0 & 0 & 0 & 1 & -1 & 0 & 60 \\
\hline$x_{3}$ & $\frac{7}{5}$ & 0 & 1 & $-\frac{1}{20}$ & 0 & 0 & $-\frac{1}{10}$ & $\frac{3}{20}$ & 7 \\
\hline$x_{2}$ & $-\frac{4}{25}$ & 1 & 0 & $\frac{3}{25}$ & 0 & 0 & $\frac{1}{25}$ & $-\frac{4}{25}$ & $\frac{36}{5}$ \\
\hline
\end{tabular}

Berdasarkan Tabel 5, karena nilai ruas kanan pada pembatas tidak ada yang bernilai negatif, maka iterasi tidak perlu dilanjutkan. Sehingga, diperoleh hasil optimum dan fisibel yang disajikan dalam Tabel dibawah berikut:

Tabel 6. Hasil Optimasi Tabel Dual Simpleks

\begin{tabular}{cc}
\hline Variabel keputusan & Hasil akhir \\
\hline$z$ & 1.633 .000 \\
\hline$s_{1}$ & 20 \\
\hline$s_{2}$ & 60 \\
\hline$x_{3}$ & 7 \\
\hline$x_{2}$ & $\frac{36}{5}$ \\
\hline
\end{tabular}


Berdasarkan Tabel 6 di atas, dapat disimpulkan bahwa kelompok wanita tani (KWT) Sentosa Santul harus menyediakan pupuk jenis Phonska sebanyak $\frac{36}{5}$ karung, pupuk jenis

NPK Zamrud 7 karung dengan biaya minimum sebesar RP. 1.633.000.

\subsection{Penyelesaian menggunakan Metode Quick Simpleks}

Metode quick simpleks memakai tabel dengan sekali iterasi untuk mencapai solusi optimum dan fisibel. Langkah-Langkah penyelesaian metode quick simpleks sebagai berikut:

Langkah 1: Menyusun model program linier

a. Menentukan variabel keputusan

$x_{1}$ : Jumlah pupuk jenis Hidrokompleks yang harus disediakan

$x_{2}$ : Jumlah pupuk jenis Phonska yang harus disediakan

$x_{3}$ : Jumlah pupuk jenis NPKZamrud yang harus disediakan

$x_{4}$ : Jumlah pupuk jenis pupuk kandang Kambing yang harus disediakan

b. Menentukan fungsi tujuan

Min $z=225000 x_{1}+115000 x_{2}+115000 x_{3}+35000 x_{4}$

c. Menentukan fungsi kendala:

$$
\begin{aligned}
& 15 x_{1}+15 x_{2}+16 x_{3}+2 x_{4} \geq 200 \\
& 9 x_{1}+15 x_{2}+16 x_{3}+x_{4} \geq 160 \\
& 20 x_{1}+15 x_{2}+16 x_{3}+x_{4} \geq 220 \\
& 4 x_{1}+10 x_{2}+4 x_{3}+x_{4} \geq 100 \\
& x_{1}, x_{2}, x_{3}, x_{4} \geq 0
\end{aligned}
$$

Langkah 2: Menyusun model program linier kedalam bentuk standar

Karena semua pembatas dalam Persamaan 7 di atas merupakan pembatas dengan tanda $\geq$, maka penyelesaian persoalan tersebut dapat diselesaikan menggunakan metode dual simpleks. Langkah pertama yang harus dilakukan adalah mengubah pembatas tanda $\geq$ menjadi tanda $\leq$ dengan mengalikan -1 pada setiap kendala. Setelah diperoleh pertidaksamaan dengan kendala bertanda $\leq$, kemudian mengubah model ke dalam bentuk standar dengan menambahkan variabel slack yaitu: $s_{1}, s_{2}, s_{3}, s_{4}$ sebagai berikut :

$$
\begin{aligned}
& \text { Maks } z=-225000 x_{1}-115000 x_{2}-115000 x_{3}-35000 x_{4} \\
& \text { kendala } \\
& \quad-15 x_{1}-15 x_{2}-16 x_{3}-2 x_{4}+S_{1}=-200 \\
& \quad-9 x_{1}-15 x_{2}-16 x_{3}-x_{4}+S_{2}=-160 \\
& \quad-20 x_{1}-15 x_{2}-16 x_{3}-x_{4}+S_{3}=-220 \\
& \quad-4 x_{1}-10 x_{2}-4 x_{3}-x_{4}+S_{4}=-100 \\
& \quad x_{1}, x_{2}, x_{3}, x_{4}, S_{1}, S_{2}, S_{3}, S_{4} \geq 0
\end{aligned}
$$

Langkah 3: Menyusun Persamaan (8) kedalam bentuk tabel awal simpleks

Tabel 7. Tabel awal metode quick simpleks

\begin{tabular}{cccccccccc}
\hline $\mathrm{VB}$ & $x_{1}$ & $x_{2}$ & $x_{3}$ & $x_{4}$ & $\mathrm{NK}$ & $s_{1}$ & $s_{2}$ & $s_{3}$ & $s_{4}$ \\
\hline$Z$ & $-22500 \mathrm{C}$ & $-11500 \mathrm{C}$ & $-11500 \mathrm{C}$ & $-3500 \mathrm{C}$ & 0 & 0 & 0 & 0 & 0 \\
\hline$s_{1}$ & $x_{11}=-15$ & $x_{12}=-15$ & $x_{13}=-16$ & $x_{14}=-2$ & $b_{1}=-200$ & 1 & 0 & 0 & 0 \\
\hline$s_{2}$ & $x_{21}=-9$ & $x_{22}=-15$ & $x_{23}=-16$ & $x_{24}=-1$ & $b_{2}=-160$ & 0 & 1 & 0 & 0 \\
\hline$s_{3}$ & $x_{31}=-20$ & $x_{32}=-15$ & $x_{33}=-16$ & $x_{34}=-1$ & $b_{3}=-220$ & 0 & 0 & 1 & 0 \\
\hline
\end{tabular}




$$
\begin{array}{cccccccccc}
s_{4} & x_{41}=-4 & x_{42}=-10 & x_{43}=-4 & x_{44}=-1 & b_{4}=-100 & 0 & 0 & 0 & 1 \\
\hline
\end{array}
$$

NK: nilai ruas kanan

Langkah 4 : Menentukan leaving variable

Leaving variable dipilih dari variabel basis yang memiliki ruas kanan yang

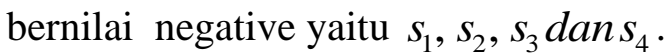

Langkah 5 : Menentukan entering variable

Entering variable dipilih ketika elemen-elemen penting dalam entering variable berada dalam baris yang berbeda. Entering variable dipilih berdasarkan perbandingan (rasio) antara koefisien persamaan $z$ dengan koefisien persamaan leaving variable yang memiliki harga negatif dan dimulai dari negatif terbesar dari variabel basis. Untuk persoalan minimasi entering variable adalah variabel dengan rasio positif terkecil. Jika terdapat nilai entering variable yang sama, maka dipilih salah satu.

Tabel 8. Entering variable untuk $\left(s_{3}=-220\right)$

\begin{tabular}{|c|c|c|c|c|c|c|c|c|}
\hline & $x_{1}$ & $x_{2}$ & $x_{3}$ & $x_{4}$ & $s_{1}$ & $s_{2}$ & $s_{3}$ & $s_{4}$ \\
\hline Koefisien persamaan $z$ & $-22500 \mathrm{C}$ & -115000 & -115000 & -35000 & 0 & 0 & 0 & 0 \\
\hline Koefisien persamaan $s_{3}$ & -20 & -15 & -16 & -1 & 0 & 0 & 1 & 0 \\
\hline Rasio & 11250 & 76666 & 7187,5 & $3500 \mathrm{C}$ & 0 & 0 & 0 & 0 \\
\hline
\end{tabular}

Tabel 9. Entering variable untuk $\left(s_{1}=-200\right)$

\begin{tabular}{|c|c|c|c|c|c|c|c|c|}
\hline & $x_{1}$ & $x_{2}$ & $x_{3}$ & $x_{4}$ & $s_{1}$ & $s_{2}$ & $s_{3}$ & $s_{4}$ \\
\hline Koefisien persamaan $z$ & $-22500 C$ & -115000 & -115000 & -35000 & 0 & 0 & 0 & 0 \\
\hline Koefisien persamaan $s_{1}$ & -15 & -15 & -16 & -2 & 1 & 0 & 0 & 0 \\
\hline Rasio & 15000 & 76666 & 7187,5 & $1750 \mathrm{C}$ & 0 & 0 & 0 & 0 \\
\hline
\end{tabular}

Perhitungan yang sama dilakukan untuk menentukan entering variable untuk $s_{2}$ dan $s_{4}$.

Berdasarkan Tabel 8, Tabel 9 serta perhitungan untuk $s_{2}$ dan $s_{4}$ diperoleh elemen pivot berada dalam basis yang sama yaitu untuk $\left(s_{3}=-220\right)=x_{3}=7187,5$; $\left(s_{1}=-200\right)=x_{3}=7187,5$ dan $\left(s_{2}=-160\right)=x_{3}=7187,5$. Karena $s_{1}, s_{2}$ dan $s_{3}$ elemen pivot berasa dalam basis yang sama yaitu $x_{3}$ maka pilih salah satu $\left(s_{3}\right)$. Sedangkan $s_{4}$ diperoleh elemen pivot berada dalam basis yang berbeda yaitu: $\left(s_{4}=-100\right)=x_{2}=11500$. Sehingga diperoleh leaving variable yaitu $s_{3}$ dan $s_{4}$ sedangkan entering variable nya yaitu: $x_{2}$ dan $x_{3}$

Langkah 5 : Menentukan nilai $R$

$\mathrm{R}$ adalah determinan matriks dari A. Matriks A adalah susunan segi empat sikusiku dari bilangan-bilangan atau fungsi yang dibatasi dengan tanda kurung dan nilai $\mathrm{R}$ diambil dari elemen-elemen yang terdapat pada Tabel 7, dimana kolom $s_{3}, s_{4}$ (leaving variable) dan $x_{2}, x_{3}$ (entering variable). Maka menggunakan rumus $\mathrm{R}$ untuk dua variabel secara simultan dan kolom baris yang lain tidak dimasukkan dalam R. Nilai R disajikan dalam Tabel 10 berikut: 
Tabel 10 Metode quick simpleks untuk R

\begin{tabular}{|c|c|c|c|c|c|c|c|c|c|}
\hline VB & $x_{1}$ & $x_{2}$ & $x_{3}$ & $x_{4}$ & NK & $S_{1}$ & $s_{2}$ & $s_{3}$ & $s_{4}$ \\
\hline$z$ & $-22500 C$ & $-11500 C$ & $-11500 C$ & $-3500 \mathrm{C}$ & 0 & 0 & 0 & 0 & 0 \\
\hline$s_{1}$ & $x_{11}=-15$ & $x_{12}=-15$ & $x_{13}=-16$ & $x_{14}=-2$ & $b_{1}=-200$ & 1 & 0 & 0 & 0 \\
\hline$s_{2}$ & $x_{21}=-9$ & $x_{22}=-15$ & $x_{23}=-16$ & $x_{24}=-1$ & $b_{2}=-160$ & 0 & 1 & 0 & 0 \\
\hline$s_{3}$ & $x_{31}=-20$ & $x_{32}=-15$ & $x_{33}=-16$ & $x_{34}=-1$ & $b_{3}=-220$ & 0 & 0 & 1 & 0 \\
\hline$S_{4}$ & $x_{41}=-4$ & $x_{42}=-10$ & $x_{43}=-4$ & $x_{44}=-1$ & $b_{4}=-100$ & 0 & 0 & 0 & 1 \\
\hline
\end{tabular}

Sehingga, didapatkan matriks A adalah sebagai berikut:

$$
A=\left|\begin{array}{lllll}
x_{11} & x_{12} & x_{13} & x_{14} & b_{1} \\
x_{21} & x_{22} & x_{23} & x_{24} & b_{2} \\
x_{31} & x_{32} & x_{33} & x_{34} & b_{3} \\
x_{41} & x_{42} & x_{43} & x_{44} & b_{4}
\end{array}\right|=\left|\begin{array}{ccccc}
-15 & -15 & -16 & -2 & -200 \\
-9 & -15 & -16 & -1 & -160 \\
-20 & -15 & -16 & -1 & -220 \\
-4 & -10 & -4 & -1 & -100
\end{array}\right|
$$

Karena leaving variable dan entering variable ada dua, maka menentukan nilai $\mathrm{R}$ menggunakan rumus dua variabel secara simultan, sehingga diperoleh nilai R:

$$
R=\left|\begin{array}{ll}
x_{32} & x_{33} \\
x_{42} & x_{43}
\end{array}\right|=\left|\begin{array}{cc}
-15 & -16 \\
-10 & -4
\end{array}\right|=60-160=-100
$$

Langkah 6 : Menentukan nilai elemen untuk tabel simpleks baru

Karena leaving variable dan entering variable ada dua, maka menggunakan rumus untuk dua variabel secara simultan dan didapatkan tabel simpleks baru yang disajikan dalam Tabel hasil optimasi metode quick simpleks. 
Tabel 11. Nilai elemen baru metode quick simpleks

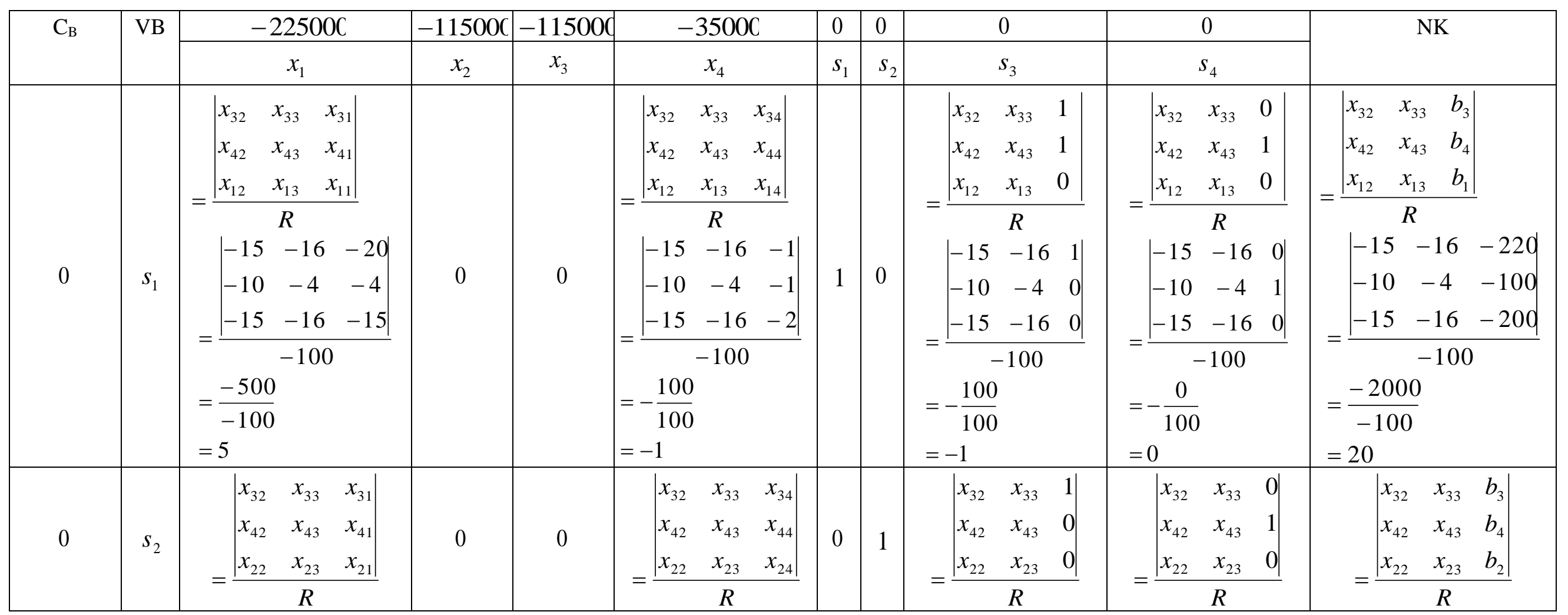


JOURNAL OF FUNDAMENTAL MATHEMATICS AND APPLICATIONS (JFMA) VOL. 4 NO. 1 (JUN 2021)

Available online at www.jfma.math.fsm.undip.ac.id

\begin{tabular}{|c|c|c|c|c|c|c|c|c|c|c|}
\hline & & $\begin{array}{l}=\frac{\left|\begin{array}{lll}-15 & -16 & -20 \\
-10 & -4 & -4 \\
-15 & -16 & -9\end{array}\right|}{-100} \\
=\frac{-1100}{-100} \\
=11\end{array}$ & & & $\begin{array}{l}=\frac{\left|\begin{array}{lll}-15 & -16 & -1 \\
-10 & -4 & -1 \\
-15 & -16 & -1\end{array}\right|}{-100} \\
=-\frac{0}{100} \\
=0\end{array}$ & & & $\begin{array}{l}=\frac{\left|\begin{array}{ccc}-15 & -16 & 1 \\
-10 & -4 & 0 \\
-15 & -16 & 0\end{array}\right|}{-100} \\
=-\frac{100}{100} \\
=-1\end{array}$ & $\begin{array}{l}=\frac{\left|\begin{array}{ccc}-15 & -16 & 0 \\
-10 & -4 & 1 \\
-15 & -16 & 0\end{array}\right|}{-100} \\
=-\frac{0}{100} \\
=0\end{array}$ & $\begin{array}{l}=\frac{\left|\begin{array}{lll}-15 & -16 & -220 \\
-10 & -4 & -100 \\
-15 & -16 & -160\end{array}\right|}{-100} \\
=\frac{-6000}{-100} \\
=60\end{array}$ \\
\hline$-11500 \mathrm{c}$ & $x_{3}$ & $\begin{aligned}= & \frac{(-1)^{2}\left|\begin{array}{ll}x_{32} & x_{31} \\
x_{42} & x_{41}\end{array}\right|}{R} \\
= & \frac{(-1)^{2}\left|\begin{array}{ll}-15 & -20 \\
-10 & -4\end{array}\right|}{-100} \\
= & \frac{(64-80)}{-100} \\
= & \frac{-140}{-100}=\frac{7}{55}\end{aligned}$ & 0 & 1 & $\begin{array}{l}=\frac{(-1)^{2}\left|\begin{array}{ll}x_{32} & x_{34} \\
x_{42} & x_{44}\end{array}\right|}{R} \\
=\frac{(-1)^{2}\left|\begin{array}{ll}-15 & -1 \\
-10 & -1\end{array}\right|}{-100} \\
=\frac{(15-10)}{-100} \\
=-\frac{5}{100}=-\frac{1}{20}\end{array}$ & 0 & 0 & $\begin{array}{l}=\frac{(-1)^{2}\left|\begin{array}{ll}x_{32} & 1 \\
x_{42} & 0\end{array}\right|}{R} \\
=\frac{(-1)^{2}\left|\begin{array}{ll}-15 & 1 \\
-10 & 0\end{array}\right|}{-100} \\
=\frac{(0-(-10))}{-100} \\
=-\frac{10}{100}=-\frac{1}{10}\end{array}$ & $\begin{array}{l}=\frac{(-1)^{2}\left|\begin{array}{ll}x_{32} & 0 \\
x_{42} & 1\end{array}\right|}{R} \\
=\frac{(-1)^{2}\left|\begin{array}{ll}-15 & 0 \\
-10 & 1\end{array}\right|}{-100} \\
=\frac{(-15-0)}{-100} \\
=\frac{-15}{-100}=\frac{3}{20}\end{array}$ & $\begin{array}{c}=\frac{(-1)^{2}\left|\begin{array}{ll}x_{32} & b_{3} \\
x_{42} & b_{4}\end{array}\right|}{R} \\
=\frac{(-1)^{2}\left|\begin{array}{cc}-15 & -22 \\
-10 & -100\end{array}\right|}{-100} \\
=\frac{1500-2200}{-100}=\frac{-700}{-100}\end{array}$ \\
\hline$-11500 \mathrm{c}$ & $x_{2}$ & $=\frac{(-1)^{1}\left|\begin{array}{ll}x_{33} & x_{31} \\
x_{43} & x_{41}\end{array}\right|}{R}$ & 1 & 0 & $=\frac{(-1)^{1}\left|\begin{array}{ll}x_{33} & x_{34} \\
x_{43} & x_{44}\end{array}\right|}{R}$ & 0 & 0 & $=\frac{(-1)^{1}\left|\begin{array}{ll}x_{33} & 1 \\
x_{43} & 0\end{array}\right|}{R}$ & $=\frac{(-1)^{1}\left|\begin{array}{ll}x_{33} & 0 \\
x_{43} & 1\end{array}\right|}{R}$ & $=\frac{(-1)^{1}\left|\begin{array}{ll}x_{33} & b_{3} \\
x_{43} & b_{4}\end{array}\right|}{R}$ \\
\hline
\end{tabular}




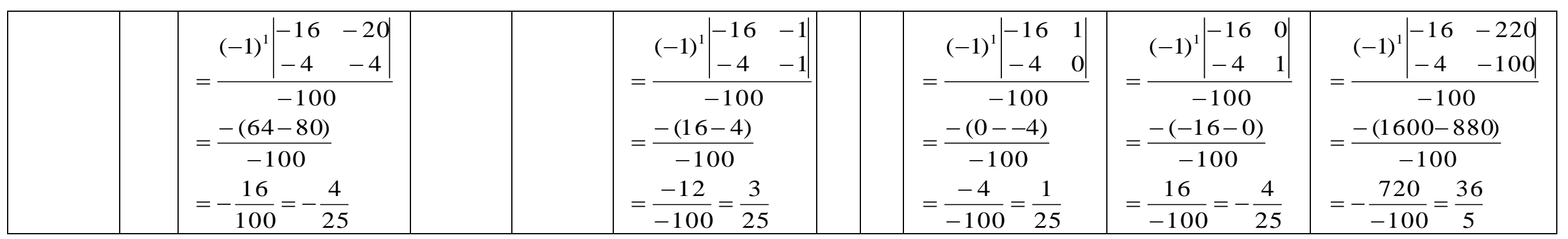

NK: Nilai ruas kanan

Menentukan nilai $z_{j}-c_{j}$ digunakan rumus pada Persamaan (3):

$$
\begin{aligned}
& z_{j}-c_{j}: \max x_{1} \rightarrow\left((0) .(5)+(0) .(11)+(-115.000) \cdot\left(\frac{7}{5}\right)+(-115.000) \cdot\left(\frac{4}{25}\right)-(-225.000)\right)=82.400 \\
& \min x_{1}=-82.400 \\
& z_{j}-c_{j}: \max x_{4} \rightarrow\left((0) \cdot(-1)+(0) \cdot(0)+(-115.000) \cdot\left(-\frac{1}{20}\right)+(-115.000) \cdot\left(\frac{3}{25}\right)-(-35.000)\right)=26.950 \\
& \min x_{4}=-26.950 \\
& z_{j}-c_{j}: \max s_{3} \rightarrow\left((0) .(-1)+(0) .(-1)+(-115.000) .\left(-\frac{1}{10}\right)+(-115.000) \cdot\left(\frac{1}{25}\right)-(0)\right)=6.900 \\
& \min s_{3}=-6.900 \\
& z_{j}-c_{j}: \max s_{4} \rightarrow\left((0) .(0)+(0) .(0)+(-115.000) .\left(\frac{3}{20}\right)+(-115.000) .\left(-\frac{4}{25}\right)-(0)\right)=1.150 \\
& \min s_{4}=-1.150 \\
& z_{j}-c_{j}: \max N K \rightarrow\left((0) .(0)+(0) .(0)+(-115.000) .(7)+(-115.000) .\left(\frac{36}{5}\right)-(0)\right)=-1.633 .000 \\
& \min N K=1.633 .000
\end{aligned}
$$


Berdasarkan Tabel 11 menunjukkan bahwa hasil optimasi nilai ruas kanan tidak bernilai negatif, maka solusi sudah optimal dan fisibel. Sehingga diperoleh hasil optimum dan fisibel yang disajikan dalam tabel dibawah berikut:

Tabel 12. Hasil optimasi tabel quick simpleks

\begin{tabular}{cc}
\hline Variabel keputusan & Hasil akhir \\
\hline$Z$ & 1.633 .000 \\
\hline$s_{1}$ & 20 \\
\hline$s_{2}$ & 60 \\
\hline$x_{3}$ & 7 \\
\hline$x_{2}$ & $\frac{36}{5}$ \\
\hline
\end{tabular}

Berdasarkan Tabel hasil optimasi quick simpleks dapat disimpulkan bahwa kelompok wanita tani (KWT) Sentosa Santul harus menyediakan pupuk jenis Phonska sebanyak $\frac{36}{5}$ karung, pupuk jenis NPK Zamrud 7 karung dengan biaya minimum sebesar RP. 1.633.000.

Berdasarkan hasil pembahasan diperoleh bahwa metode quick simpleks lebih efisien dibandingkan dengan metode dual simpleks, hal ini dapat dilihat dari banyaknya iterasi yang dilakukan dan waktu pengerjaan yang lebih singkat karena metode quick simpleks pengambilan leaving variable dan entering variable bisa diambil dua sekaligus secara simultan yang bernilai negatif. Sehingga, solusi optimal dan fisibel metode dual simpleks diperoleh dengan melakukan iterasi sebanyak dua kali iterasi dan quick simpleks satu kali iterasi.

\section{KESIMPULAN}

Berdasarkan hasil penelitian, dapat di ambil kesimpulan bahwa dari kedua metode yaitu metode dual simpleks dan quick simpleks menghasilkan nilai yang sama. Sehingga diperoleh hasil bahwa kelompok wanita tani (KWT) Sentosa Santul tidak menyediakan pupuk jenis Hidrokompleks dan pupuk jenis kandang kambing, tetapi kelompok wanita tani (KWT) Sentosa Santul harus menyediakan pupuk jenis Phonska sebanyak $\frac{36}{5}$ karung, pupuk jenis NPK Zamrud 7 karung dengan biaya minimum untuk pemupukan sebesar RP. 1.633.000. 


\section{REFERENSI}

[1] Alfian, R, "Efisiensi Usaha Tani Cabai Merah di Lahan Pasir Pantai di Desa Pleret Kecamatan Panjatan Kabupaten Kulon Progo", Skripsi. Fakultas Pertanian. Universitas Muhammadiyah Yogyakarta, 2017.

[2] Dimyati, Tjutju dan Dimyati Ahmad, Operation Research: Model-Model Pengambilan Keputusan. Bandung: Sinar Baru Algesindo, 2009.

[3] Gupta, Premer Kumar dan Hira D. S.“Operation Research”. Fifth Revised Edition S.Chand and Company Ltd. 2010.

[4] Hiller, Frederick S. and Lieberman, Gerald J. "Introduction to Operation Research". Mc Graw- hill Publishing Company, New York. 2001.

[5] Runhayat, A. "Penentuan Kebutuhan Pokok Unsur Hara N, P, K untuk pertumbuhan Tanaman Panili (Vanilla Planifolia Andrews). Bul. Littro. Vol. XVIII No. 1. 2007

[6] Sutedjo, M. M, Pupuk dan Cara Pemupukan. Jakarta: PT. Rineka Cipta hlm 177, 1999.

[7] Ulya, Wazna, "Penerapan metode Cutting Plane untuk optimasi biaya pemupukan pada tanaman cabai (Studi kasus: Kelompok Wanita Tani Sentosa Santul)", Skipsi. Fakultas Sains dan Teknologi. Program Studi Matematika, 2019.

[8] Vaidya NV, dan Kasturiwale NN. "Comparison between various entering vector criteria with quick simplex algorithm for optimal solution to the linear programming problem". International Journal of Mathematics and Statistics Invention (IJMSI). 2(6):17-36. Available: www.ijmsi.org E- ISSN: 2321 - 4767, P-ISSN: 2321 - 4759. 2014.

[9] Vaidya NV, dan Kasturiwale NN. "Quick simplex algorithm for optimal solution to the linear programming problem along with theoretical proof of formulae". Int. J Latest Trend Math, (IJLTM). (E-ISSN-2049- 2561). 4(2):183-200. 2014.

[10] Vaidya NV, dan Kasturiwale NN. "Approximation algorithm for optimal solution to the linear programming problem”. Int. J. Mathematics in Operational Research, Vol. 6, No. 2. 2014.

[11] Vaidya N. V dan Kasturiwale N.N, "Application of Quick Simplex Method (A New Approach) on two phase method". British Journal of Mathematics \& Computer Science. Science domain International., 16 (1) : 1 - 15 : Article no. BJMCS . 24440 ISSN: 2231-0851, 2016.

[12] Vaidya N.V dan Kasturiwale N.N, "Application of quick simplex method on the dual simplex method (A New Approac)'". British Journal of Mathematics \& Computer Science. Science domain International., 24 (5) : 1 - 19 : Article no. JAMCS . 36357 ISSN: 2231-0851, 2017. 